\title{
Incidence of Galls on Sympatric California Oaks: Ecological and Physiological Perspectives
}

\author{
Ramón Perea ${ }^{1,2, * \mathbb{D}}$, Rodolfo Dirzo ${ }^{1,3}$, Stephanie Bieler ${ }^{1}$ and Geraldo Wilson Fernandes ${ }^{1,4}(\mathbb{D}$ \\ 1 Department of Biology, Stanford University, 327 Campus Drive, Stanford, CA 94305, USA; \\ rdirzo@stanford.edu (R.D.); bieler.stephanie@gmail.com (S.B.); gw.fernandes@gmail.com (G.W.F.) \\ 2 Departmento de Sistemas y Recursos Naturales, Universidad Politécnica de Madrid, \\ C/José Antonio Novais 10, 28040 Madrid, Spain \\ 3 Woods Institute for the Environment, Stanford University, Stanford, CA 94305, USA \\ 4 Departmento de Genética, Evolução e Ecologia, Universidade Federal de Minas Gerais, \\ 30161 Belo Horizonte, Brazil \\ * Correspondence: ramon.perea@upm.es
}

check for updates

Citation: Perea, R.; Dirzo, R.; Bieler, S.; Wilson Fernandes, G. Incidence of Galls on Sympatric California Oaks: Ecological and Physiological Perspectives. Diversity 2021, 13, 20. https://doi.org/10.3390/d13010020

Received: 2 December 2020

Accepted: 2 January 2021

Published: 6 January 2021

Publisher's Note: MDPI stays neutral with regard to jurisdictional clai$\mathrm{ms}$ in published maps and institutional affiliations.

Copyright: $\odot 2021$ by the authors. Licensee MDPI, Basel, Switzerland. This article is an open access article distributed under the terms and conditions of the Creative Commons Attribution (CC BY) license (https:// creativecommons.org/licenses/by/ $4.0 /)$.

\begin{abstract}
Galls are abnormal outgrowths on the external tissues of plants caused by a restricted group of organisms. In this study, we surveyed the incidence and diversity of galling structures in sympatric oak species of a biological preserve (Jasper Ridge Biological Preserve, NC, USA). We also measured different physiological parameters (SLA-specific leaf area, chlorophyll, nitrogen, flavonol, anthocyanin, and water content) in galled and ungalled leaves on the same individuals of the most abundant oak species (Quercus agrifolia, Q. lobata, and Q. douglasii). Overall, Q. lobata showed the highest gall incidence, with $64.5 \%$ of the sampled leaves affected by galls, followed by $Q$. douglasii, $Q$. agrifolia, $Q$. durata, and $Q$. kelloggii. The proportion of stems with galls was considerably lower than for leaves in all oak species, ranging from $0 \%$ incidence in $Q$. kelloggii to $27.4 \%$ in Q. lobata. The highly schlerophyllous Q. agrifolia supported the most diverse galling community at Jasper Ridge, with ten species, mostly belonging to the Cynipidae family. Our results show that leaf galling had no significant impact on the studied ecophysiological variables. The lack of differences between galled and ungalled leaves under controlled conditions (same tree and position in the tree) suggests that the ecophysiological variables measured are not significantly affected by galling agents or that our data collected for fully-developed galls (end of summer) are not sensitive enough to detect differences. However, there were some trends in plant responses to galling. Changes in galled vs. ungalled leaves were greater in flavonols, followed by chlorophyll, nitrogen, anthocyanin, SLA, and water content, indicating a nutrient deficiency in the plant nutrients. Our findings underscore the complexity of the gall-plant interaction and suggest some promising lines of future research.
\end{abstract}

Keywords: Quercus; Northern California; gall incidence; leaf ecophysiology; insect galling

\section{Introduction}

Galling is a particular case of herbivory caused by a relatively restricted group of organisms that induce the host plant's morpho-functional capacities [1,2]. Among galling animals, insects are the most abundant and, consequently, are present on a wide range of host plants. Once oviposited into plant tissue, these insects induce the generation of a gall, a plant growth abnormality that varies in shape, size, and structure depending on the insect species [3]. The insect's immature stages (nymphs or larvae) use this gall as a home for part of their life cycle, while being fed by the plant and avoiding the plant's defensive compounds, and some natural enemies [1,4]. Although relatively similar in their basic function, galls vary considerably in phenotypic traits (morphology, size, structure, and chemistry) to protect the larva from predation and parasitoid attack and to increase the likelihood of a successful life cycle $[3,5]$. Galling insects have undergone considerable 
speciation - with around 100,000 species of gall-inducing insects worldwide [6], and form a wide variety of gall structures in different plant organs $[2,7,8]$.

The complexity of the interaction between galling insects and their host plants has been studied for a long time [7], yet we still know very little about galling insect ecology. For instance, host selection and the impact of galls on plant performance and physiology remain elusive [9]. Apparently, gall-inducing insects are most abundant, most diverse, and have the highest survival rate in sclerophyllous vegetation $[10,11]$ and are also most commonly found on trees, followed by shrubs and herbs [12]. Gall-inducing insects are considered highly specific [13], since each species predominantly interacts with only one host plant or closely related species, although this relationship is asymmetrical—a plant species can host a variety of gall-inducing insects [9]. There is also substantial evidence that habitat stress is a central factor in determining the patterns of galling-insect richness in many ecosystems, whereby plants inhabiting more stressful environments tend to be more attacked by galling insects [10,11].

Eco-geographically speaking, galling is present in most ecosystems, including tropical and temperate regions. Among the latter, oak trees (Quercus spp.) are important and dominant components in the Northern Hemisphere, forming part of highly diverse systems that provide numerous ecosystem services to society. In California, oak woodlands support more than 1400 species of flowering plants and over 300 species of vertebrates [14] and, therefore, harbor complex networks of species interactions [15]. Over 140 species of gall-inducing wasps (Hymenoptera: Cynipidae) lay their eggs in various tissues of oak populations from the Western USA [16]. Virtually, all native California oak species are hosts to one or more gall wasp species, which in turn can colonize several to many oak species [17]. Although the most conspicuous galls are the so-called oak apples ("manzanitas"), many other galls are present within a guild of sympatric oak species (see below).

It has been argued that most oak galls, especially leaf galls, cause little or no lasting damage to oaks [16,17]. However, a few galls cause limited leaf or twig dieback by blocking the vascular tissue [17]. Interestingly, senesced oak galls can provide habitat for predatory arthropods, such as spiders and ants, which attack herbivorous invertebrates [18,19], thus potentially serving as top-down controls of oak herbivory.

Studies that have examined whether the plant vigor hypothesis (the hypothesis that herbivores prefer healthy, "vigorous" plants or plant parts over less vigorous, stressed plants or plant parts [20]) have yielded mixed results in the case of galling herbivory [21-23]. For example, in California, the oak gall-inducing wasp Andricus spp. preferred vigorous, large-diameter shoots over thin ones of comparable age [24]. Therefore, there is still debate as to whether oak galling insects prefer stressed plants, healthy plants, or have no preference.

Despite early suggestions to the contrary, there is accumulating evidence that galling insects can have a negative impact on its host plant. Several studies have illustrated that galling insects act as physiological sinks by extracting resources from neighboring plant modules [25-28]. Therefore, stress responses could extend to other adjacent organs [26]. Ferreira et al. [29] found that Clusia lanceolata leaves galled by a cecidomyiid fly contained a higher total phenolic content than non-galled leaves and concluded that the high content of tannins in the galled leaves was an induced, defensive response to galling. This suggests that, at least in some instances, galling represents a cost to the host plant, but this is an aspect that warrants further research. Additionally, galling insects have been found to have a negative impact on plant performance in terms of decreased levels of growth, shorter-lived leaves, and shorter shoots in Persea borbonia [30].

The magnitude of galling on a given plant seems to be an important factor in determining impact. For example, higher densities of galls were found to have greater impact on plant growth [31,32]. A study with Alnus glutinosa showed that heavily infested gall shoots had significantly smaller final leaf areas [33]. In California, a study on Quercus gambelli showed that gall density decreased with maturity of the host plant [24]. Given that certain regions and climates support a high abundance of galling insects (e.g., the Mediterranean 
oak woodlands, [11]), differences in plant stress responses could be a result of higher densities of galling insects.

Although information is still limited, this set of studies illustrates the potential negative impact of galling insects on plant vegetative and reproductive performance. This is further supported by Hartley [34], who found that there were clear differences between galled and ungalled tissues in terms of both nutrient levels and levels of secondary compounds: galled plant tissues generally contained lower levels of nitrogen and higher levels of phenolic compounds than ungalled tissue. It is therefore important to determine exactly how and to what extent galls are eliciting these negative responses.

While most of the research on the effects of galling has focused on the impacts on plant performance, there is a considerable knowledge lacuna regarding the underlying ecophysiological traits of galled versus ungalled leaves within the same individual, or even within the same plant organ of the individual (e.g., branch). This is important in order to tease apart the effect of the gall from possible confounding factors such as individual variation and even leaf position within the phylotaxis of a given branch. There are also compounds that are produced as a result of plant stress. Anthocyanins, water-soluble pigments derived from flavonoids, are often induced as a result of nutrient deficiencies [35] or herbivory, be that seed predation or browsing [36,37]. A reduction in nutrient availability will also cause a plant to reduce its photosynthetic capacity, which would lead to a reduction in chlorophyll content [38]. The elucidation of these complexities motivated the present study. By surveying the incidence of galling and then measuring these different compound levels in galled and ungalled leaves on the same individual in sympatric species, we examine possible leaf responses to galling.

Specifically, we aimed to examine the patterns and impact of galling insects on several California oak species in order to: (1) Quantify inter-specific variation in galling incidence across a guild of sympatric host oak species in Northern California; (2) Document the diversity of galling insects for each host oak species; and (3) Examine possible differences in oak physiological responses to galling via the comparison between replicated pairs of galled and ungalled leaves of comparable size and same location within the tree.

\section{Materials and Methods}

\subsection{Study Area}

The study was conducted at the Jasper Ridge Biological Preserve (JRBP), located in the foothills of the Santa Cruz Mountains, Northern coastal California, CA, USA ( $37.40^{\circ} \mathrm{N}$, $122.23^{\circ} \mathrm{W}$ ). JRBP, a 480-hectare research preserve with an elevation range of $66-207 \mathrm{~m}$ a.s.l., experiences a coastal Mediterranean climate, with warm, dry summers and cool, wet winters. Mean annual precipitation is $605 \mathrm{~mm}$ and daily temperatures range from $2-4{ }^{\circ} \mathrm{C}$ (winter) to $25-27^{\circ} \mathrm{C}$ (summer) [39]. The preserve's edaphology includes alluvial soils, tertiary sandstone soils, chert, and serpentine [40]. JRBP supports diverse vegetation types including grassland, woodland, chaparral, and mixed forest. Oak-dominated systems (woodlands and savannas) are the most common vegetation type in JRBP [41]. These systems are dominated by an evergreen oak, Quercus agrifolia Née (sect. Erythrobalanus), and two deciduous species (sect. Leucobalanus): Q. lobata Née in deeper soils, and Q. douglasii Hook. \& Arn. in shallower, drier soils. In addition, serpentine areas include individuals of the evergreen Quercus durata Jepson, and there are a few individuals of the extremely rare $Q$. kelloggii Newb. sparsely distributed throughout woodland areas of the preserve. Compared to Q. agrifolia, both Q. lobata and $Q$. douglasii have lower tannin content and larger acorns [42,43] and are preferred by browsers (largely mule deer) over Q. agrifolia [37]. The most common shrub species in the study area are Baccharis pilularis and Toxicodendron diversilobum (Torr. \& A. Gray) Greene). 


\subsection{Data Collection}

\subsubsection{Gall Incidence Surveys}

We conducted quantitative observations of the overall incidence of galls on a sample of trees of all five oak species present in the preserve. For the three most abundant species, Q. agrifolia, $Q$, lobata, and $Q$. douglasii, we sampled 5-6 trees from three independent stands (separated by at least $1 \mathrm{~km}$ from each other) dominated by these species, for a total of 18,16 , and 16 trees, respectively. For the locally very rare oak $Q$. kelloggii, we sampled trees present in two small patches where they are prevalent ( $n=3$, and $n=4$ trees). For the serpentinespecialized oak, $Q$. durata, we sampled 6 trees from each of two serpentine grassland patches present at the preserve. Within each stand of each of the species, we haphazardly selected the trees to be sampled. Sampling was restricted to the part of a tree's crown that could be reached by stretching one's arms and using a 1-m pole with a hook at the tip, allowing us to reach branches of up to $3.3 \mathrm{~m}$ in height. An effort was made to sample trees of about the same size for each of the species except for serpentine oak. The smaller trees of this species allowed us to sample from the entire canopy. Thus, within each species, the sampling protocol was consistent. From each tree, we haphazardly selected five branches by walking around the tree's crown, to secure samples from all around its canopy. This, and the marking of each selected branch with flagging tape, insured that we sampled independent branches and that we did not re-sample the same branches within each tree. Moving from the distal part of the branch, towards the basal part of it, we examined all leaves and stems (for a maximum length of $50 \mathrm{~cm}$ of the branch) for the presence/absence of galls (of all types/species) on both leaves and stems. New, unfolded and senescent leaves were not included in the sampling. Thus, our variable for quantifying incidence of galls is the proportion of galled leaves or stems per branch. The sum of the values derived from the five branches yields the percentage of galling (for leaves and stems) per tree.

\subsubsection{Diversity of Galls on Oaks}

We performed surveys within JRBP in two consecutive years (2015-2016) for the three most abundant oak species: Q. agrifolia, Q. lobata, and Q. douglasii. Observations were conducted in spring and summer to detect as much as possible of the site's diversity of gall-inducing taxa. Twenty oak trees for each species were visited throughout the scattered oak woodlands of JRBP. For each tree, ten large (between $50-80 \mathrm{~cm}$ ) branches were haphazardly selected around the canopy (below $2.5 \mathrm{~m}$ high) and all the leaves and stems were examined in search of galls. Each gall structure was photographed or sampled for further identification. Incidence for each galling-inducing taxa was recorded as the percentage of trees hosting the specific gall structure.

\subsubsection{Leaf Physiological Responses to Galling}

This part of the study focused on the three most abundant oaks: Q. agrifolia, Q. douglasii, and Q. lobata. Each of these oak species is host to several species of galling arthropods, including Eriophyes mackiei, Andricus crystallinus, and Antron douglasii, respectively, which were the most prominent galling species. The galling E. mackiei is a mite (Acarina: Eriophyidae) that causes blister-like swellings, which protrude from the upper leaf surface of its host plant [17] (Figure 1). The mites feed and reproduce within those blisters [17]. The host of E. mackiei, Q. agrifolia, is a drought-resistant monoecious evergreen tree of California [44], which inhabits the lower elevation oak woodlands. The galling insect Andricus crystalli$n u s$ is characterized as a cynipid leaf gall (Hymenoptera: Cynipidae), which is found in virtually all California oak species [17]. It produces a gall of varying shades of pink and is densely covered with white, red, or brown hairs [45] (Figure 1). The galling insect $A$. douglasii is also a cynipid (Hymenoptera: Cynipidae) leaf gall [46]. Its gall is a star-shaped, red to purplish structure with blunted horns [46] (Figure 1). Like A. crystallinus, the larvae of $A$. douglasii matures within the gall and then emerges to complete the next generation, and its larvae does not grow until the gall structure is mature [17]. 


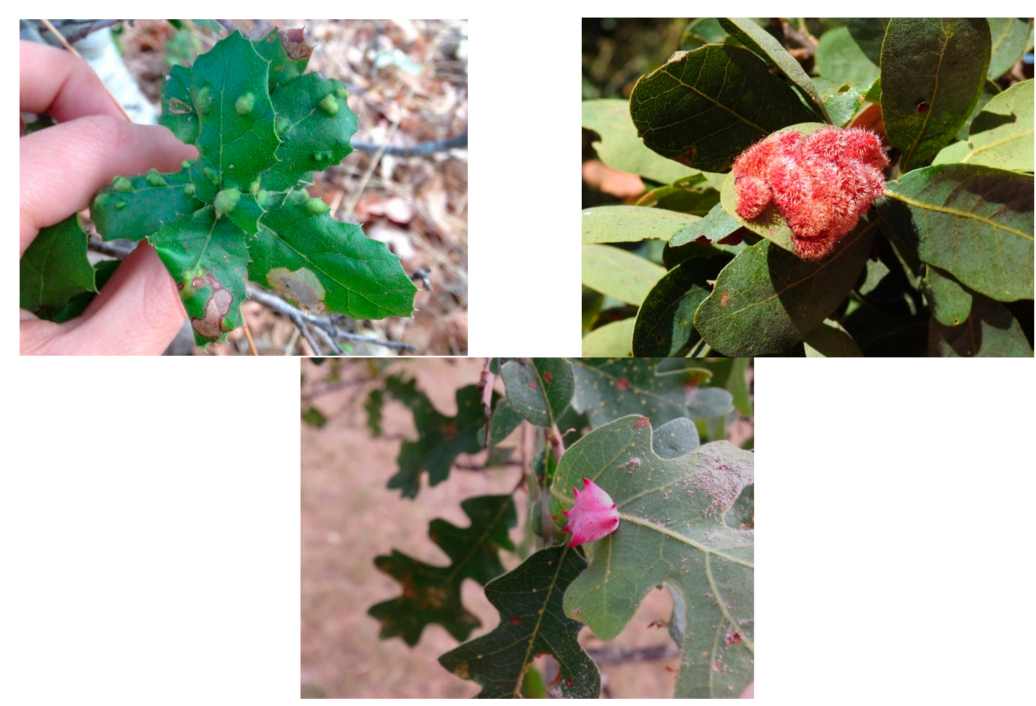

Figure 1. The galling mite Eriophyes mackiei on the host Quercus agrifolia (top left). The galling insect Andricus crystallinus on the host Quercus douglasii (top right). The galling insect Antron douglasii on the host Quercus lobata (bottom).

We sampled 10 individuals for each oak species: Q. agrifolia, Q. lobata, and Q. douglasii. Each individual sampled was at least ten meters apart from another individual of the same species. All oak trees were adult trees of similar size, with DBH (diameter at breast height, of $1.3 \mathrm{~m}$ height) greater than $7.5 \mathrm{~cm}$. The study design was based on a matched-pair protocol. For each individual, we selected six pairs of branches. For each pair, one had leaves containing at least one gall (galled branch) and one had no signs of galls on any leaves (ungalled branch). Branches within the same pair experienced similar abiotic and biotic conditions (same relative age, same position and similar amount of light, similar distance from the tree trunk, and exposure to the same herbivores). One galled and ungalled leaf was collected from the galled and ungalled branches, respectively. For the galled branch, the adjacent leaf immediately below the galled leaf (or stem gall) was collected and, for the ungalled branch, the leaf taken had the equivalent position (i.e., phylotaxis) of the leaf taken from the galled branch (same number of fully expanded leaves away from the apical meristem). For the evergreen oak $Q$. agrifolia, leaves could be older than 1 year old. A total of 360 leaves were sampled ( 3 species $\times 10$ individuals $\times 6$ pairs $\times 2$ leaves per pair). Leaves taken from galled branches are referred to as galled leaves, and leaves taken from ungalled branches are referred to as ungalled leaves. Leaf collection took place during the months of September and October 2015, towards the end of the dry season at Jasper Ridge Biological Preserve to ensure that the trees had sufficient time to respond to insect galling during the growing season.

Once collected, the leaf samples were placed in a cooler and taken to the lab for further measurements. In the lab, we measured five leaf traits from the fresh leaves using the Dualex Scientific $+{ }^{\mathrm{TM}}$ Polyphenol and Chlorophyll-meter: flavonol content, anthocyanin content, and chlorophyll content. In addition, we measured specific leaf area and water content. The Dualex is a non-destructive leaf-holding device that can accurately measure chlorophyll content in leaves and flavonol and anthocyanin content in the epidermis utilizing the different light wavelengths released by the different particles [47-49]. In addition, the Dualex device provides the $\mathrm{NBI}^{\circledR}$ (Nitrogen Balance Index), which is the Chlorophyll/Flavonols ratio (related to Nitrogen/Carbon allocation) that can be used as a proxy for the nitrogen status of plants [50,51]. More details of Dualex indexes can be found in [51,52]. Chlorophyll content and NBI were used to determine plant health. In order to measure water content and SLA (Specific Leaf Area), we cut circles of a uniform diameter (for each species) out of the leaves and weighed them. The leaf disk for each species varied depending upon the size of the leaf but was the same within each branch pair. We performed all fresh leaf measurements within twelve hours of collecting the 
leaves. Once we completed the fresh leaf measurements, we placed the labeled leaf disks in an oven at 70 degrees Celsius for at least $48 \mathrm{~h}$ in order to dry the leaves to a constant weight. We then weighed the dried leaf disks. Based upon the techniques used to calculate SLA and water content in [53], water content was calculated as [1-(disk fresh weight/disk dry weight) $] \times 100$, and SLA was calculated as fresh disk area $\left(\mathrm{cm}^{2}\right)$ divided by disk dry weight $(\mathrm{g})$.

\subsubsection{Statistical Analyses}

All data were analyzed with R 4.0.2 [54]. We used beta regression models to analyze leaf gall incidence (percentage of leaves affected within each sampled stem) following [55]. Fixed effect (predictor) was oak species. The beta regression model was fitted with a logit link function (that with the highest pseudo R2) to obtain the predicted (fitted) values, using the "betareg" package [55] in R. For stem gall incidence, we built a Generalized Linear Model with binary distribution where the response variable was binary (stem galled or not, binomial error distribution), and the fixed effect was the species. Tree stands were not considered as random effects due to their low number of factor levels [56]. The model was fitted by the Laplace approximation with a logit link function according to our data properties [56], using the "glm" function within the "lme4" package. We built the violin plots (i.e., a box plot with a rotated kernel density plot on each side) for each oak species for both leaf and stem gall incidence, using the "vioplot" function of R. For the diversity of galling agents, we used descriptive statistics (percentage of trees affected by each galling agent).

To analyze whether any of the measured physiological variables was a statistically significant predictor of leaf galling, we used General Linear Mixed Models (GLMM's). The six variables were rescaled to avoid convergence. Each oak individual was entered as a random effect in the GLMM. The response variable for all analyses was whether a leaf was galled or ungalled (binary response), and all GLMM's were fit to a binomial distribution with a logit link function. All GLMM's were built using the "glmer" function (Laplace approximation), included in the "lme4" package for R. We used the model averaging approach to summarize all the competing models and to make a stronger inference. Model averaging involves the calculation of a weighted average for a particular predictor across a set of models. The weighting is provided by the Akaike information criterion (AIC) weights. The AIC weights were also used to calculate the importance of a predictor (from 0 to 1 ), which is the sum of the AIC weights across all the models, where that particular predictor occurs. We first fitted the maximal model, containing all the predictors and then performed a comparison of all possible models by using the AIC weights. The "dredge" function included in the "MuMIn" package for R was used to generate the set of models. To present the results of the GLMM, we created a combined graph (histograms plus logistic curves), following the recommendations of [57]. To obtain these graphs, we used the 'plot.logi.hist' function from the 'pobbio' library of R.

\section{Results}

\subsection{Gall Incidence Surveys}

Overall, $Q$. lobata showed the highest gall incidence values, with $64.5 \%$ of the sampled leaves affected by galls, followed by Q. douglasii, Q. agrifolia, Q. durata, and Q. kelloggii (Figure 2A). Interestingly, the proportion of stems with galls was considerably lower than for leaves in all oak species, ranging from $0 \%$ incidence in Q. kelloggii to $27.4 \%$ in Q. lobata (Figure 2B). 

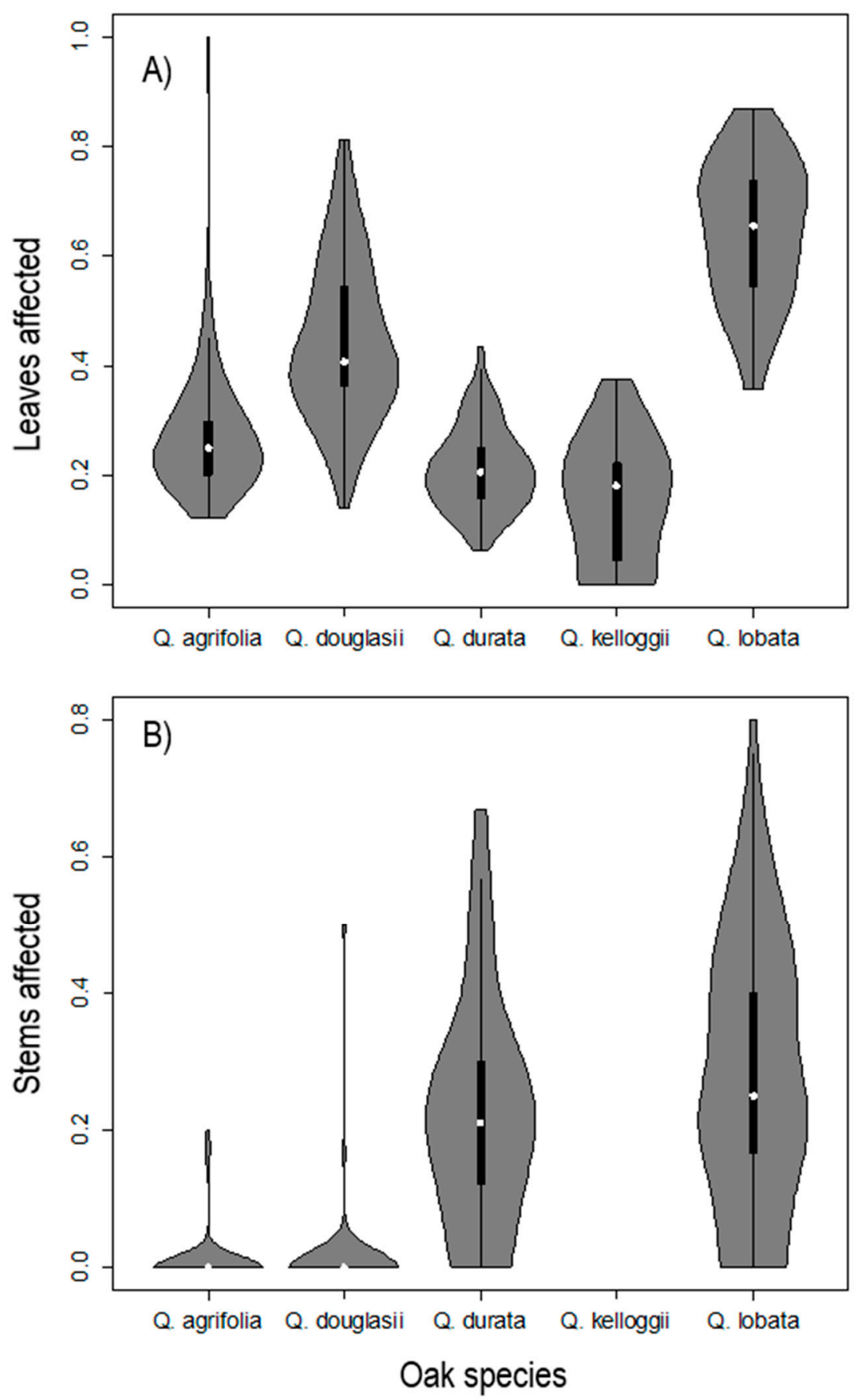

Figure 2. Violin plots showing the probability of gall incidence for leaves (A) and stems (B) of the five sympatric oak species at Jasper Ridge Biological Preserve, Northern California, USA. The violin plots show the median values of the data (white dot) with a box indicating the interquartile range and a rotated kernel density plot on each side.

There was significant inter-specific variation in leaf gall incidence $\left(\chi^{2}{ }_{4}=692.38\right.$; $p<0.001$ ), with all species being significantly different from each other (Table S1; Figure 2A). Inter-specific variation was also statistically significant in the case of stem gall incidence $\left(\chi_{4}^{2}=247.09 ; p<0.001\right)$. Quercus durata and Q. lobata represented a statistically homogeneous group $(p>0.05)$ of stem-galled species, which was significantly different from the other three species that had none or negligible incidence ( $p<0.05$; Table S2; Figure 2B). 


\subsection{Diversity of Oak Galls}

The evergreen and highly schlerophyllous $Q$. agrifolia supported the most diverse galling community at Jasper Ridge, with ten species, including a mite gall induced by Eriophyes mackiei (Figure 3A). On this host, one gall structure was induced by a cecidomyiid. It was located on leaves and formed by simple leaf rolling (Contarinia sp.) at the leaf margin, and induction of simple swelling of discoid shape. Eight out of ten galling agents on Q. agrifolia are cynipid wasps (Table 1; Figure 3A). The deciduous oak, Q. lobata, presented only five galling insects, all of them cynipids of four different genera (Table 1; Figure 3B). Seven different organisms induced galls on Q. douglasii (Table 1; Figure 3C), all of them being cynipids of six different genera (Table 1 ).
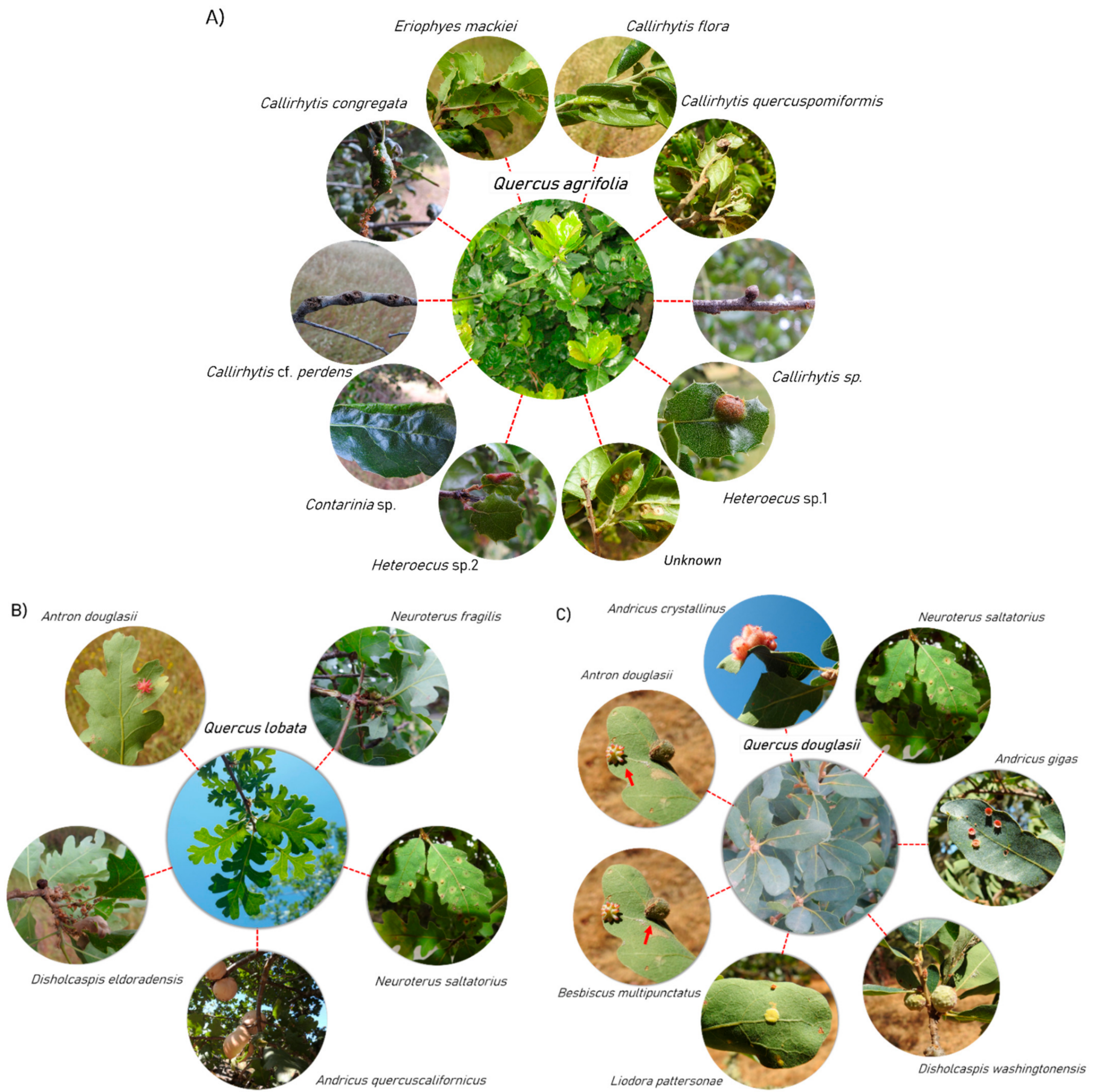

Figure 3. Oak galls on Quercus agrifolia (A), Q. lobata (B) and Q. douglasii (C) at Jasper Ridge Biological Preserve, Northern California, USA. 
Table 1. Galling agents, taxonomic family, host species, host organ and incidence (percentage of trees affected) for the three main Quercus species at Jasper Ridge Biological Preserve (Northern California).

\begin{tabular}{|c|c|c|c|c|}
\hline Galling Agent & Family & Host Species & Host Organ & Incidence $(\%)$ \\
\hline Callirhytis congregata & Cynipidae & Q. agrifolia & Catkin & $83 \%$ \\
\hline Eriophyes mackiei & Eriophyidae & Q. agrifolia & Leaf & $83 \%$ \\
\hline Callirhytis flora & Cynipidae & Q. agrifolia & Leaf & $83 \%$ \\
\hline Callirhytis quercuspomiformis & Cynipidae & Q. agrifolia & Leaf & $17 \%$ \\
\hline Callirhytis sp. & Cynipidae & Q. agrifolia & Stem & $33 \%$ \\
\hline Heteroecus sp1 & Cynipidae & Q. agrifolia & Leaf & $50 \%$ \\
\hline Unknown & - & Q. agrifolia & Leaf & $17 \%$ \\
\hline Heteroecus sp2 & Cynipidae & Q. agrifolia & Leaf & $33 \%$ \\
\hline Contarinia sp. & Cecidomyiidae & Q. agrifolia & Leaf & $33 \%$ \\
\hline Callirhytes cf. perdens & Cynipidae & Q. agrifolia & Stem & $17 \%$ \\
\hline Neuroterus fragilis & Cynipidae & Q. lobata & Leaf & $33 \%$ \\
\hline Neuroterus saltatorius & Cynipidae & Q. lobata & Leaf & $83 \%$ \\
\hline Andricus quercuscalifornicus & Cynipidae & Q. lobata & Stem & $33 \%$ \\
\hline Disholcaspis eldoradensis & Cynipidae & Q. lobata & Stem & $33 \%$ \\
\hline Antron douglasii & Cynipidae & Q. lobata and Q. douglasii & Leaf & $67 \%$ and $83 \%$ \\
\hline Andricus crystallinus & Cynipidae & Q. douglasii & Leaf & $83 \%$ \\
\hline Neuroterus saltatorius & Cynipidae & Q. douglasii & Leaf & $83 \%$ \\
\hline Andricus gigas & Cynipidae & Q. douglasii & Leaf & $83 \%$ \\
\hline Disholcaspis washingtonensis & Cynipidae & $\widetilde{Q} \cdot$ douglasii & Stem & $67 \%$ \\
\hline Liodora pattersonae & Cynipidae & Q. douglasii & Leaf & $33 \%$ \\
\hline Besbiscus multipunctatus & Cynipidae & Q. douglasii & Leaf & $50 \%$ \\
\hline
\end{tabular}

\subsection{Leaf Physiological Responses to Galling}

Overall, none of the physiological variables were found to be statistically significant predictors for determining whether a leaf was galled or ungalled. The variable with the highest AIC weight (most important variable in explaining the probability of being galledungalled) across all oak species was flavonol content, with a relative importance of 0.68 out of 1 (Table 2). Chlorophyll, anthocyanins, and NBI were the next most important variables, with very similar relative importance values (Table 2). Finally, SLA and water content were the least important variables (Table 2).

Table 2. Summary of the GLMM Model Averaging ( $n=64$ models) to test the overall relative importance of each ecophysiological parameter in explaining gall presence across all species. A negative average estimate indicates that galled leaves had lower levels of the measured variable than ungalled leaves. $z$-value and $p$-value come from averaged models.

\begin{tabular}{cccccc}
\hline Predictors & Relative Importance & Averaged Estimate & Standard Error & z-Value & $p$-Value \\
\hline Flavonol Content & 0.68 & -0.2208919 & 0.1464645 & 1.506 & 0.132 \\
Chlorophyll & 0.51 & -0.1083698 & 0.3353858 & 0.323 & 0.747 \\
Anthocyanin Content & 0.50 & 0.1558205 & 0.1143836 & 1.360 & 0.174 \\
Nitrogen Balance Index & 0.50 & -0.1979788 & 0.3764416 & 0.525 & 0.599 \\
Specific Leaf Area & 0.43 & 0.1161805 & 0.0998047 & 1.162 & 0.245 \\
Water Content & 0.30 & -0.0457975 & 0.0928121 & 0.493 & 0.622 \\
\hline
\end{tabular}

Across all species, leaves that were galled showed lower NBI, flavonol content, chlorophyll content, and water content compared to ungalled leaves (Figure 4). Conversely, anthocyanin content and SLA were slightly positively associated with galled leaves (Figure 4). 

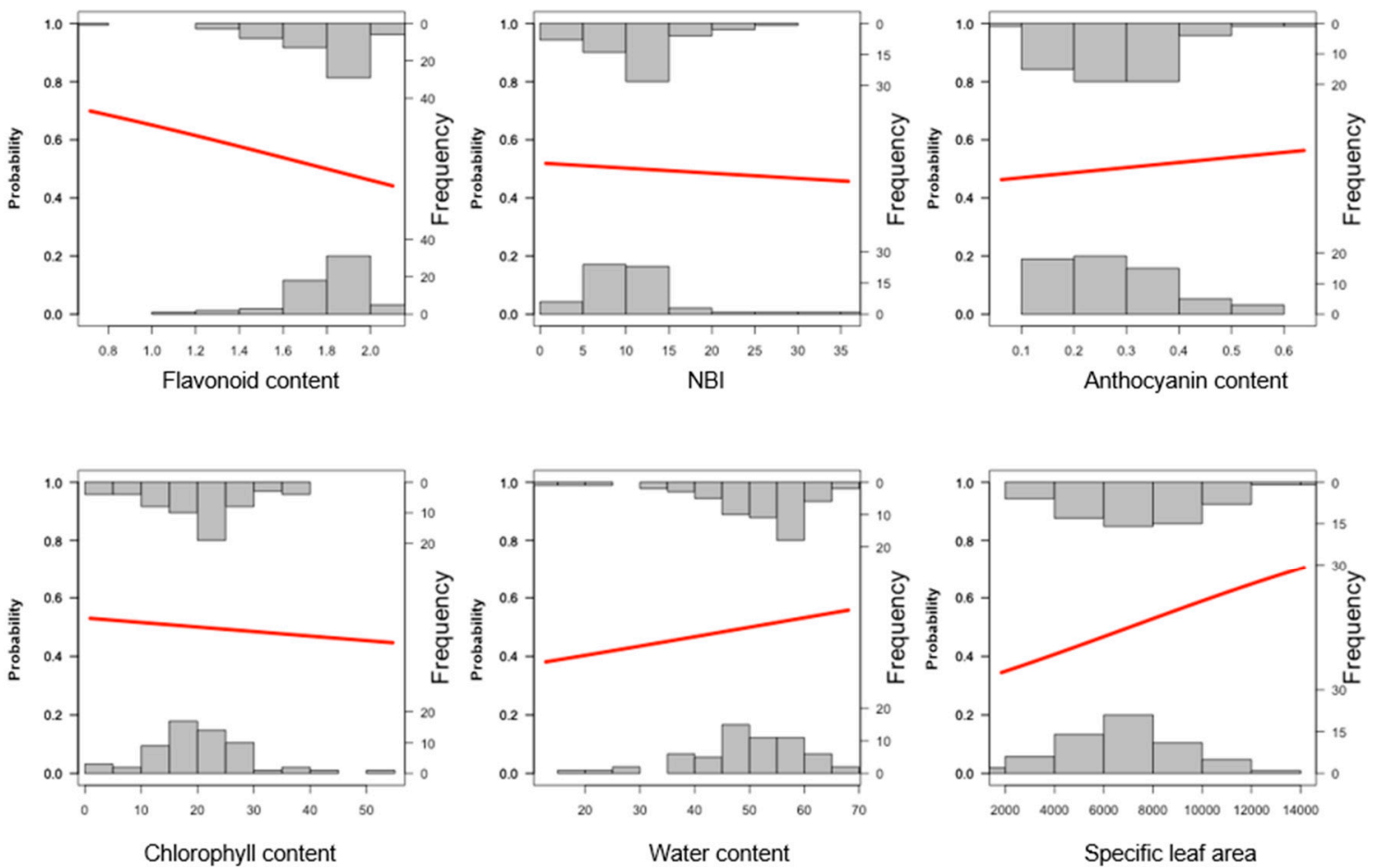

Figure 4. Fitted logistic regression curves showing the predicted probability of gall presence across the study physiological variables. The histograms represent the observed data ( $1=$ galled leaf; $0=$ ungalled leaf $)$ and the line shows the predicted probability. $\mathrm{n}=64$ models.

\section{Discussion}

\subsection{Gall Incidence Surveys}

Our results show that gall incidence strongly varied across oak species and the host organ (leaf vs. stem) in line with previous studies. For instance, Leckey et al. [58] reported low gall incidence on $Q$. agrifolia trees (10\% affected) as compared to $Q$. douglasii $(80 \%)$. In our study area, $Q$. douglasii and $Q$. lobata showed the greatest incidence values for leaf galling, whereas $Q$. lobata and $Q$. durata showed the highest stem galling incidence. Stem galls, usually caused by cynipid wasps, were also commonly observed in California oaks [59] but were clearly less common than leaf galls across the five study species. Going forward, the study of inter-annual, as well as intra-annual (seasonal) variation in galling incidence, as well as the sampling of the entire canopy, are aspects that warrant further research.

Many gall wasp species have two alternating generations, a bisexual (usually in winter and early spring on permanent structures such as stems) and a unisexual (only females, typically during late spring and summer producing galls on leaves and catkins) [45,60-62]. This means that stem vs. leaf incidence values may strongly depend on the time of survey as very few leaves might be affected or may go inconspicuous in early spring. Thus, we advocate for late summer surveys when both leaf and stem galls are conspicuous. Interestingly, drier climates tend to have higher survivorship for gall-inducing insects $[4,63]$. Thus, the coastal oak woodlands with milder summers may have lower gall abundance than the interior oak woodlands of California where the climate is drier and hotter, and woodlands are typically dominated by $Q$. douglasii [64]. Nevertheless, further long-term studies are necessary to evaluate the impact of increasing temperature and aridity on the abundance and survivorship of California oak galls for both the bisexual and asexual generations, particularly under the current global warming context. The present study can be used as a baseline for such long-term surveys, along with measurements of abiotic (climatic) variables. 


\subsection{Diversity of Oak Galls}

Our results show that the gall wasps (Cynipidae) are the most diverse group of gallinginducing agents in oaks in agreement with many previous studies $[65,66]$. Indeed, about $82 \%$ (roughly 1300 species) of cynipids use oaks for their home [66,67]. Surprisingly, in our study system, we found a greater gall diversity for $Q$. agrifolia, even though previous studies indicate that $Q$. douglasii harbors the greatest diversity of all oaks [68]. Quercus agrifolia is by far the most abundant oak species in the study area, which may explain the greater abundance and diversity of galls as compared to other co-occurring oak species given that gall-inducing agents are highly species-specific [69-71]. Previous studies also showed that galling species are particularly diverse in dry and sclerophyllous vegetation [63], which may explain that $Q$. agrifolia and $Q$. douglasii have greater diversity than the deciduous and more mesic $Q$. lobata. In addition, we could expect greater diversity in dominant and widespread species such as $Q$. agrifolia and $Q$. douglasii as compared to $Q$. lobata, which mostly occurs at scattered remnant patches [64].

As long known, cynipids radiated into the genus Quercus [72], and this is clearly observed in this survey at JRBP. Quercus spp. represents a superhost complex [73] for galling wasps and hence an important system to observe species formation and differential resistance/susceptibility to herbivory [71]. Interestingly, very few gall-inducing taxa were found outside the Cynipidae family, with the mite Eriophyes mackiei (Eriophyidae; Arachnida) as one of the most widespread gall inducing agents in the evergreen Q. agrifolia. Further studies should explore the diversity of gall-inducing taxa, including both types of generations as their galls and adult morphs can differ considerably in size, form, color, and seasonal occurrence from the corresponding generation [9,67]. As pointed by Evans [61], the generations are so different that their relationship becomes apparent only through careful rearing and field observation, or with the use of genetic analysis.

\subsection{Leaf Physiological Responses to Galling}

Our results show that leaf galling agents had no significant impact on the studied ecophysiological variables. The lack of differences between galled and ungalled leaves under controlled conditions (same tree and position in the tree) suggests that the ecophysiological variables measured in this study are not significantly affected by galling agents in the selected sympatric oak species, or that our methods are not sensitive enough to detect differences. Many studies have shown that oak leaf galls, even though they are common, very seldom had a significant impact on oak health $[17,59,74]$. Another possible explanation for the lack of plant response to the presence of galling insects is plant compensation. Within the context of herbivory, there is an established gradient of plant responses to herbivore attack, known as the Plant Response Continuum, that can manifest in several different metrics of plant performance, including both growth and reproduction [75]. The plant's capacity to compensate is determined by its ability to increase its carbohydrate production [76]. This can be done through increased photosynthetic capacity as seen in Cucumis sativus, or via the mobilization of carbohydrates from storage organs, such as roots or stems [76]. A plant's response to herbivory can range from a compensatory response, where the plant compensates for the negative impact of herbivory so that it is indistinguishable from undamaged plants, to over-compensation, where the plant's performance is considerably better than that of plants that are not affected by herbivory [75]. It has been found that, when plants experience relatively low levels of damage, such as when less than $15 \%$ of the leaf area is damaged, compensatory effects are frequent [77]. This sort of compensatory response could manifest in plant organs within the same plant when the plant organs experience contrasting levels of herbivory, especially if the herbivory causes little damage. There is evidence that, under controlled conditions, plants are able to recover from galling insect attacks if sufficient resources are available, but there is no evidence that plants display this kind of compensatory response in field conditions when they are experiencing more stressful conditions [78]. Importantly, ecophysiological impact on galled plants is typically observed early on the galling process $[31,79,80]$. As the plant 
matures and grows larger, the sink-source relationship and impact on the host plant may diminish or reach an equilibrium point [81-83]. Therefore, further studies should address the ecophysiological response earlier in the galling process and, ideally, compare early vs. late responses to galling. In fact, the trade-offs among nutrients, water, and chemistry are important at this phase [84]. As gall develops, the galling larvae totally control plant genome and then plant cells and tissues become true extended phenotypes of the galling larva [85-87]. However, it is difficult to measure any physiological variables on a leaf bud when the galling process begins. Thus, most studies only focus on fully-developed galls and further studies on earlier galling stages are warranted. In addition, stem galls, although rarer, might be more appropriate for evaluating the ecophysiological response of oaks to galling as the nutrient flow inside the branch might be partially interrupted causing physiological changes beyond the galling point.

Despite the lack of significant differences in ecophysiological responses to galling insect herbivory, there were some trends in plant responses to galling insects. These responses provide some insights into how plants may be affected by the presence of galling insects. The model averaging approach allowed us to establish a ranking of the variables and established their relative importance. Overall, flavonol content was the most important variable with a high relative importance value $(0.68)$, followed by chlorophyll content, NBI, and anthocyanin content, which showed very similar relative importance values $(\sim 0.50)$. These four ecophysiological variables are all indicators of a plant responding to stress. Changes in flavonol content indicate a nutrient deficiency in the plant, which is supported by the idea that galling insects have been found to act as a nutrient sink and therefore would deprive nearby plant tissues of nutrients [34]. Changes in chlorophyll content, NBI, and anthocyanin content would indicate a similar type of stress response to the presence of a galling insect, which would explain why their rankings of relative importance were somewhat similar $[35,38]$. The lower relative importance of water content and SLA could be a result of plant life history and external conditions. In studies reporting that galling insects produced water stress in plants, the host plant tended to have a much shorter life cycle than oaks [87]. Furthermore, the leaves for the study were sampled at the end of the dry season in JRBP, so the oaks were most likely experiencing water stress when they were sampled. Additionally, the marked difference in the importance of ecophysiological parameters illustrates that a more comprehensive study of plant stress responses to galling insect presence needs to be performed. There are several studies that indicate that galling insects can have impacts on plants that are not related to the plant's indirect stress response. For example, Fernandes et al. [88] found that the presence of galling insects led to an increased abscission in leaflets compared to leaflets that were not galled. Additionally, galling insects have been found to lower plant fitness by reducing its chemical defense against subsequent herbivores even though the plant did not respond to the presence of the galling insect [89]. Galling insects have also been found to have a negative impact on plant-reproductive output due to their proximity to the ovaries of the plant Phillyrea angustifolia [90]. Therefore, not only is it important to continue to measure nutrient deficiency and water stress, but it is also critical to systematically examine all the possible ways in which galling insects affect plant performance. Our findings underscore the complexity of the gall-plant interaction and suggest some promising lines of future research that may help us improve our understanding of this intriguing type of herbivory.

Supplementary Materials: The following are available online at https:/ / www.mdpi.com/1424-2 $818 / 13 / 1 / 20 /$ s1, Table S1: Summary of the beta regression model to analyze leaf gall incidence. Species are shown against Q. agrifolia, Table S2. Summary of the Generalized Linear Model to analyze stem gall incidence. Species are shown against $Q$. agrifolia.

Author Contributions: R.D. and G.W.F. conceived the ideas, collected part of the data, wrote some parts of the text, and revised the drafts; S.B. collected part of the data, performed some statistical analysis, and wrote some parts of the text; R.P. collected part of the data, performed most of the statistical analysis, wrote substantial parts of the Ms (first draft), and coordinated the work. All authors have read and agreed to the published version of the manuscript. 
Funding: R.P. was supported by a Marie Curie International Outgoing Fellowship from European Commission (FP7-PEOPLE-2013-IOF-627450). R.D. was supported by unrestricted funds from Stanford's School of Humanities and Sciences. G.W.F. was supported by CNPq, Capes, and Fapemig. The project GLOBALFOR supported by UPM and Comunidad de Madrid (Convenio Plurianual for young researchers) also provided financial support.

Data Availability Statement: The data presented in this study are available in Supplementary Material here.

Acknowledgments: We thank the staff at the Stanford Jasper Ridge Biological Preserve, Northern California (USA) for providing support to conduct the fieldwork. Gui Gomez provided help with fieldwork pertaining galling incidence.

Conflicts of Interest: The authors declare no conflict of interest.

\section{References}

1. Price, P.W.; Fernandes, G.W.; Waring, G.L. Adaptive nature of insect galls. Environ. Entomol. 1987, 16, 15-24. [CrossRef]

2. Stone, G.N.; Schönrogge, K. The adaptive significance of insect gall morphology. Trends Ecol. Evol. 2003, 18, 512-522. [CrossRef]

3. Shorthouse, J.D.; Rohfritsche, O. Biology of Insect-Induced Galls; Oxford University Press: New York, NY, USA, 1992.

4. Fernandes, G.W.; Price, P.W. The adaptive significance of insect gall distribution: Survivorship of species in xeric and mesic habitats. Oecologia 1992, 90, 14-20. [CrossRef] [PubMed]

5. Betancourt, E.K.; Soto, P.H.; Cortés, N.C.; Anaya, M.R.; Estrella, A.H.; Oyama, K. Ecological Genomics of Plant-Insect Interactions: The Case of Wasp-Induced Galls. In Evolutionary Ecology of Plant-Herbivore Interaction; Núñez-Farfán, J., Valverde, P., Eds.; Springer: Cham, Switzerland, 2020; pp. 315-341.

6. Espírito-Santo, M.M.; Fernandes, G.W. How many species of gall-inducing insects are there on Earth, and where are they? Ann. Entomol. Soc. Am. 2007, 100, 95-99.

7. Price, P.W. Adaptive radiation of gall-inducing insects. Bas. Appl. Ecol. 2005, 6, 413-421. [CrossRef]

8. Schultz, J.C.; Edger, P.P.; Body, M.J.A.; Appel, H.M. A galling insect activates plant reproductive programs during gall development. Sci. Rep. 2019, 9, 1833. [CrossRef] [PubMed]

9. Shorthouse, J.D.; Wool, D.; Raman, A. Gall-inducing insects-Nature's most sophisticated herbivores. Bas. Appl. Ecol 2005, 6, 407-411. [CrossRef]

10. Julião, G.R.; Venticinque, E.M.; Fernandes, G.W.; Price, P.W. Unexpected high diversity of galling insects in the Amazonian upper canopy: The savanna out there. PLoS ONE 2014, 9, e114986. [CrossRef]

11. Fernandes, G.W.; Price, P.W. Biogeographical gradients in galling species richness. Oecologia 1988, 76, 161-167. [CrossRef]

12. Goncalves-Alvim, S.J.; Fernandes, G.W. Biodiversity of galling insects: Historical, community, and habitat effects in four neotropical savannas. Biod. Conserv. 2001, 10, 79-98. [CrossRef]

13. Abrahamson, W.G.; Melika, G.; Scrafford, R.; Csóka, G. Gall-inducing insects provide insights into plant systematic relationships. Am. J. Bot. 1998, 85, 1159-1165. [CrossRef]

14. Tyler, C.M.; Kuhn, B.; Davis, F.W. Demography and recruitment limitations of three oak species in California. Q. Rev. Biol. 2006, 81, 127-152. [CrossRef] [PubMed]

15. Davis, F.W.; Baldocchi, D.D.; Tyler, C.M. Oak Woodlands. In Ecosystems of California; Mooney, H.A., Zavaleta, E., Eds.; University of California Press: Berkeley, CA, USA, 2016; pp. 509-534.

16. Brown, L.R. Insects feeding on California oak trees. In Proceedings of the Symposium on the Ecology, Management, and Utilization of California Oaks, Claremont, CA, USA, 26-28 June 1979; Pacific Southwest Forest and Range Experiment Station: Claremont, CA, USA, 1981; Volume 44, p. 184.

17. Swiecki, T.J.; Bernhardt, E.A. A Field Guide to Insects and Diseases of California Oaks; Gen. Tech Rep. PSW-GTR-197; Pacific Southwest Research Station, Forest Service, U.S. Department of Agriculture: Albany, CA, USA, 2006.

18. Fürjes-Mikó, Á.; Csősz, S.; Csóka, G. Ants inhabiting oak Cynipid galls in Hungary. North Western J. Zool. 2006, $16,95-98$.

19. Wetzel, W.C.; Screen, R.M.; Li, I.; McKenzie, J.; Phillips, K.A.; Cruz, M.; Zhang, W.; Greene, A.; Lee, E.; Singh, N.; et al. Ecosystem engineering by a gall-forming wasp indirectly suppresses diversity and density of herbivores on oak trees. Ecology 2016, 97, 427-438. [CrossRef]

20. Price, P. The Plant Vigor Hypothesis and Herbivore Attack. Oikos 1991, 62, 244-251. [CrossRef]

21. Koricheva, J.; Larsson, S. Insect performance on experimentally stressed woody plants: A meta-analysis. Ann. Rev. Entomol. 1998, 43, 195-216. [CrossRef]

22. Fernandes, G.W. Hypersensitivity as a phenotypic basis of plant-induced resistance against a galling insect (Diptera: Cecidomyiidae). Environ. Entomol. 1998, 27, 260-267. [CrossRef]

23. Cornelissen, T.; Fernandes, G.W.; Vasconcellos-Neto, J. Size does matter: Variation in herbivory between and within plants and the plant vigor hypothesis. Oikos 2008, 117, 1121-1130. [CrossRef]

24. Pires, C.S.; Price, P.W. Patterns of host plant growth and attack and establishment of gall-inducing wasp (Hymenoptera: Cynipidae). Environ. Entomol. 2000, 29, 49-54. [CrossRef] 
25. Kirst, G.O.; Rapp, H. Physiology of gall of Mikiola fagi HTG on leaves of Fagus silvatica: Translocation of C-14 labeled assimilates from host leaf and adjacent leaves onto gall. Biochem. Physiol. Pflanz. 1974, 165, 445-455. [CrossRef]

26. Larson, K.C.; Whitham, T.G. Manipulation of food resources by a gall-forming aphid: The physiology of sink-source interactions. Oecologia 1991, 88, 15-21. [CrossRef] [PubMed]

27. Wool, D.; Aloni, R.; Ben-Zvi, O.; Wollberg, M. A galling aphid furnishes its home with a built-in pipeline to the host food supply. Entomol. Exp. Appl. 1999, 91, 183-186. [CrossRef]

28. Giron, D.; Huguet, E.; Stone, G.N.; Body, M. Insect-induced effects on plants and possible effectors used by galling and leaf-mining insects to manipulate their host plant. J. Insect. Physiol. 2016, 84, 70-89. [CrossRef] [PubMed]

29. Ferreira, R.O.; de Carvalho Junior, A.R.; da Silva, T.M.; Castro, R.N.; da Silva, T.M.; de Carvalho, M.G. Distribution of metabolites in galled and non-galled leaves of Clusia lanceolata and its antioxidant activity. Rev. Bras. Farmacogn. 2014, 24, 617-625. [CrossRef]

30. Leege, L.M. The relationship between psyllid leaf galls and redbay (Persea borbonia) fitness traits in sun and shade. Plant Ecol. 2006, 184, 203-212. [CrossRef]

31. Fernandes, G.W.; Santos, J.C.; Castro, F.M.C.; Castilho, A. Impact of gall midge Parkiamyia paraensis (Diptera, Cecidomyiidae) on the Amazon plant Parkia pendula (Fabacaeae). Rev. Bras. Entomol. 2007, 51, 471-475. [CrossRef]

32. Marini-Filho, O.J.; Fernandes, G.W. Stem galls drain nutrients and decrease shoot performance in Diplusodon orbicularis (Lythraceae). Arthropod-Plant Interact. 2012, 6, 121-128. [CrossRef]

33. Vuorisalo, T.; Walls, M.; Kuitunen, H. Gall mite (Eriophyes laevis) infestation and leaf removal affect growth of leaf area in black alder (Alnus glutinosa) short shoots. Oecologia 1990, 84, 122-125. [CrossRef]

34. Hartley, S.E. The chemical composition of plant galls: Are levels of nutrients and secondary compounds controlled by the gall-former? Oecologia 1998, 113, 492-501. [CrossRef]

35. Chalker-Scott, L. Environmental significance of anthocyanins in plant stress responses. Photochem. Photobiol. 1999, 70, 1-9. [CrossRef]

36. Perea, R.; Fernandes, G.W.; Dirzo, R. Embryo size as a tolerance trait against seed predation: Contribution of embryo-damaged seeds to plant regeneration. Perspect. Plant Ecol. Evol. Syst. 2018, 31, 7-16. [CrossRef]

37. López-Sánchez, A.; Johnson, I.; Dirzo, R.; Perea, R. Matching species traits and microsites improves regeneration in mixed oak woodlands. Appl. Veg. Sci. 2020. [CrossRef]

38. Bryant, J.P.; Chapin, F.S.; Klein, D.R. Carbon/nutrient balance of boreal plants in relation to vertebrate herbivory. Oikos 1983, 40, 357-368. [CrossRef]

39. Zavaleta, E.; Kettley, L. Ecosystem change along a woody invasion chronosequence in a California grassland. J. Arid Environ. 2006, 66, 290-306. [CrossRef]

40. Coleman, R.G. Geologic nature of the Jasper Ridge Biological Preserve, San Francisco Peninsula, California. Internat. Geol. Rev. 2004, 46, 629-637. [CrossRef]

41. Perea, R.; López-Sánchez, A.; Dirzo, R. Differential tree recruitment in California oak savannas: Are evergreen oaks replacing deciduous oaks? For. Ecol. Manag. 2017, 399, 1-8. [CrossRef]

42. Koenig, W.D. The effects of tannins and lipids on digestion of acorns by acorn woodpeckers. Auk 1991, 108, 79-88.

43. Koenig, W.D.; Faeth, S.H. Effects of storage on tannin and protein content of cached acorns. Southwest. Nat. 1998, 43, 170-175.

44. Steinberg, P.D. Quercus agrifolia. In Fire Effects Information System; U.S. Department of Agriculture, Forest Service, Rocky Mountain Research Station, Fire Sciences Laboratory (Producer): Fort Collins, CO, USA, 2002.

45. Little, R.; Swiecki, T.J.; Tietje, W. Oak Woodland Invertebrates: The Little Things Count; University of California Division of Agriculture and Natural Resources: Oakland, CA, USA, 2001.

46. Koehler, C.S. Control of Asterolecanium and cynipid leaf galls on oak in northern California. J. Econ. Entomol. 1964, 57, 579-581. [CrossRef]

47. Goulas, Y.; Cerovic, Z.G.; Cartelat, A.; Moya, I. Dualex: A new instrument for field measurements of epidermal UV-absorbance by chlorophyll fluorescence. Appl. Optics 2004, 43, 4488-4496. [CrossRef]

48. Pfündel, E.E.; Ben Ghozlen, N.; Meyer, S.; Cerovic, Z.G. Investigating UV screening in leaves by two different types of portable UV fluorimeters reveals in vivo screening by anthocyanins and carotenoids. Photosynth. Res. 2007, 93, 205-221. [CrossRef] [PubMed]

49. Cerovic, Z.G.; Masdoumier, G.; Ben Ghozlen, N.; Latouche, G. A new optical leaf-clip meter for simultaneous non-destructive assessment of leaf chlorophyll and epidermal flavonoids. Physiol. Plant. 2012, 3, 251-260. [CrossRef] [PubMed]

50. Cartelat, A.; Cerovic, Z.G.; Goulas, Y.; Meyer, S.; Lelarge, C.; Prioul, J.L.; Barbottin, A.; Jeuffroy, M.H.; Gate, P.; Agati, G.; et al. Optically assessed contents of leaf polyphenolics and chlorophyll as indicators of nitrogen deficiency in wheat (Triticum aestivum L.). Field Crops Res. 2005, 91, 35-49. [CrossRef]

51. Agati, G.; Tuccio, L.; Kusznierewicz, B.; Chmiel, T.; Bartoszek, A.; Kowalski, A.; Grzegorzewska, M.; Kosson, R.; Kaniszewski, S. Nondestructive optical sensing of flavonols and chlorophyll in white head cabbage (Brassica oleracea L. var. capitata subvar. alba) grown under different nitrogen regimens. J. Agric. Food Chem. 2016, 64, 85-94. [CrossRef] [PubMed]

52. Casa, R.; Castaldi, F.; Pascucci, S.; Pignatti, S. Chlorophyll estimation in field crops: An assessment of handheld leaf meters and spectral reflectance measurements. J. Agric. Sci. 2015, 153, 876. [CrossRef]

53. Pringle, E.G.; Adams, R.I.; Broadbent, E.; Busby, P.E.; Donatti, C.I.; Kurten, E.L.; Renton, K.; Dirzo, R. Distinct Leaf-Trait Syndromes of Evergreen and Deciduous Trees in a Seasonally Dry Tropical Forest. Biotropica 2011, 43, 299-308. [CrossRef] 
54. R Core Team. R: A Language and Environment for Statistical Computing; R Foundation for Statistical Computing: Vienna, Austria, 2020; Available online: https:/ / www.r-project.org (accessed on 15 September 2020).

55. Cribari-Neto, F.; Zeileis, A. Beta Regression in R. J. Stat. Softw. 2010, 34, 1-24. [CrossRef]

56. Bolker, B.M.; Brooks, M.E.; Clark, C.J.; Geange, S.W.; Poulsen, J.R.; Stevens, M.H.H.; White, J.S.S. Generalized linear mixed models: A practical guide for ecology and evolution. Trends Ecol. Evol. 2009, 24, 127-135. [CrossRef]

57. Smart, J.; Sutherland, W.J.; Watkinson, A.R.; Gill, J.A. A new means of presenting the results of logistic regression. Bull. Ecol. Soc. Am. 2004, 85, 100-102. [CrossRef]

58. Leckey, E.H.; Smith, D.M.; Nufio, C.R.; Fornash, K.F. Oak-insect herbivore interactions along a temperature and precipitation gradient. Acta Oecologica 2014, 61, 1-8. [CrossRef]

59. Swiecki, T.J.; Bernhardt, E.A.; Arnold, R.A. Monitoring Insect and Disease Impacts on Rangeland Oaks in California. In Proceedings of the Symposium on Oak Woodlands and Hardwood Rangeland Management, Davis, CA, USA, 31 October-2 November 1990; Gen. Tech. Rep. PSW-GTR-126; Pacific Southwest: Berkeley, CA, USA, 1991; pp. 208-213.

60. Kinsey, A.C. Phylogeny of cynipid genera and biological characteristics. Bull. Am. Mus. Nat. Hist. 1990, 42, 307-402.

61. Evans, D. The bisexual and agamaic generations of Besbicus mirabilis (Hymenoptera: Cynipidae), and their associated insects. Can. Entomol. 1967, 99, 187-196. [CrossRef]

62. Stone, G.N.; Schönrogge, K.; Atkinson, R.J.; Bellido, D.; Pujade-Villar, J. The population biology of oak gall wasps (Hymenoptera: Cynipidae). Ann. Rev. Entomol. 2002, 47, 633-668. [CrossRef] [PubMed]

63. Price, P.W.; Fernandes, G.W.; Lara, A.C.F.; Brawn, J.; Barrios, H.; Wright, M.G.; Ribeiro, S.P.; Rothcliff, N. Global patterns in local number of insect galling species. J. Biogeogr. 1998, 25, 581-591. [CrossRef]

64. Allen-Diaz, B.; Standiford, R.; Jackson, R.D. Oak woodlands and forests. In Terrestrial vegetation of California; University of California Press: Berkeley, CA, USA, 2007; pp. 313-338.

65. Russo, R. Plant Galls of the California Region; Boxwood Press: Pacific Grove, CA, USA, 1979.

66. Zargaran, M.R.; Erbilgin, N.; Ghosta, Y. Changes in Oak Gall Wasps Species Diversity(Hymenoptera: Cynipidae) in Relation to the Presence of Oak Powdery Mildew(Erysiphe alphitoides). Zool. Stud. 2012, 51, 175-184.

67. Ronquist, F.; Liljeblad, J. Evolution of the gall wasp-host plant association. Evolution 2001, 55, 2503-2522.

68. Keator, G.; Bazell, S. The Life of an Oak: An Intimate Portrait; Heyday Books and Oakland: California Oak Foundation: Berkeley, CA, USA, 1998.

69. Abrahamson, W.G.; Hunter, M.D.; Melika, G.; Price, P.W. Cynipid gall-wasp communities correlate with oak chemistry. J. Chem. Ecol. 2003, 29, 209-223. [CrossRef]

70. Cuevas-Reyes, P.; Quesada, M.; Hanson, P.; Dirzo, R.; Oyama, K.E.N. Diversity of gall-inducing insects in a Mexican tropical dry forest: The importance of plant species richness, life-forms, host plant age and plant density. J. Ecol. 2004, 92, 707-716. [CrossRef]

71. Pascual-Alvarado, E.; Nieves-Aldrey, J.L.; Castillejos-Lemus, D.E.; Cuevas-Reyes, P.; Oyama, K. Diversity of galls induced by wasps (Hymenoptera: Cynipidae, Cynipini) associated with oaks (Fagaceae: Quercus) in Mexico. Bot. Sci. 2017, 95, 461-472. [CrossRef]

72. Csóka, G.; Stone, G.N.; Melika, G. The biology, ecology and evolution of Gall-inducing Cynipidae. In Biology, Ecology and Evolution of Gall Inducing Insects; Raman, C., Schaefer, W., Withers, T.M., Eds.; CRC Press: Boca Raton, FL, USA, 2005 ; pp. 573-642.

73. Veldtman, R.; Mcgeoch, M.A. Gall-forming insect species richness along a non-scleromorphic vegetation rainfall gradient in South Africa: The importance of plant community composition. Austral. Ecol. 2003, 28, 1-13. [CrossRef]

74. Bargali, K.; Joshi, B.; Bargali, S.S.; Singh, S.P. Oaks and the biodiversity they sustain. Int. Oaks 2015, 26, 65-76.

75. Maschinski, J.; Whitham, T.G. The continuum of plant responses to herbivory: The influence of plant association, nutrient availability, and timing. Am. Nat. 1989, 134, 1-19. [CrossRef]

76. Thomson, V.P.; Cunningham, S.A.; Ball, M.C.; Nicotra, A.B. Compensation for herbivory by Cucumis sativus through increased photosynthetic capacity and efficiency. Oecologia 2003, 134, 167-175. [CrossRef] [PubMed]

77. Dirzo, R. Herbivory a Phytocentric Overview. In Perspectives in Plant Population Ecology; Dirzo, R., Sarikhan, J., Eds.; Sinauer Associates, Inc.: Sunderland, MA, USA, 1984; pp. 141-165.

78. Fay, P.A.; Hartnett, D.C.; Knapp, A.K. Plant tolerance of gall-insect attack and gall-insect performance. Ecology 1996, 77, 521-534. [CrossRef]

79. Mani, M.S. The Ecology of Plant Galls; Dr. W. Junk Publisher: The Hague, The Netherlands, 1964.

80. Roychoudhury, N.; Chandra, S.; Singh, R.B. Pest status of gall making insect, Leptocybe invasa Fisher \& Lasalle, in nurseries and plantations of Eucalyptus in Madhya Pradesh. Indian For. 2016, 142, 601-606.

81. Fonseca, C.R.; Fleck, T.; Fernandes, G.W. Processes Driving Ontogenetic Succession of Galls in a Canopy Tree 1. Biotropica 2006, 38, 514-521. [CrossRef]

82. Santos, J.C.; Fernandes, G.W. Mediation of herbivore attack and induced resistance by plant vigor and ontogeny. Acta Oecologica 2010, 36, 617-625. [CrossRef]

83. Barton, K.E.; Edwards, K.F.; Koricheva, J. Shifts in woody plant defence syndromes during leaf development. Fun. Ecol. 2019, 33, 2095-2104. [CrossRef]

84. Weis, A.E.; Walton, R.; Crego, C.L. Reactive plant tissue sites and the population biology of gall makers. Ann. Rev. Entomol. 1988, 33, 467-486. [CrossRef]

85. Dawkins, R. The Extended Phenotype; Oxford University Press: Oxford, UK, 1982. 
86. Oliveira, D.C.; Isaias, R.M.S.; Fernandes, G.W.; Ferreira, B.G.; Carneiro, R.G.S.; Fuzaro, L. Manipulation of host plant cells and tissues by gall-inducing insects and adaptive strategies used by different feeding guilds. J. Ins. Physiol. 2016, 84, 103-113. [CrossRef]

87. Florentine, S.K.; Raman, A.; Dhileepan, K. Effects of Gall Induction by Epiblema Strenuana on Gas Exchange, Nutrients, and Energetics in Parthenium Hysterophorus. BioControl 2005, 50, 787-801. [CrossRef]

88. Fernandes, G.W.; Castro, F.M.C.; Marques, E.S.A. Leaflet abscission caused by a gall induced by Melaphis rhois (Homoptera: Aphididae) on Rhus glabra (Anacardiaceae). Internat. J. Ecol. Environ. Sci. 1999, 25, 63-69.

89. Tooker, J.F.; Rohr, J.R.; Abrahamson, W.G.; De Moraes, C.M. Gall insects can avoid and alter indirect plant defenses. New Phytol. 2008, 178, 657-671. [CrossRef] [PubMed]

90. Traveset, A. Reproductive biology of Phyllyrea angustifolia. L. (Oleaceae) and effect of galling insects on its reproductive output. Bot. J. Linn. Soc. 2008, 114, 153-166. [CrossRef] 